\title{
Protein Mass and Calcium Mass of Broiler Chicken with Added Nucleotides at Different Maintenance Temperatures
}

\author{
I. Rahmawati*, L. D. Mahfudz, and S. Kismiati \\ Faculty of Animal Husbandry and Agriculture, Diponegoro University \\ Jl. Prof. Soedharto No. 13 Tembalang, Kec. Tembalang, Semarang City, Central Java 50275 \\ * Corresponding Author: rahmawatida1108@gmail.com
}

\begin{abstract}
This study aims to examine the effect of adding nucleotides in broiler rations on the protein mass and calcium mass of broiler chicken reared at different temperatures. The material used was 135 broiler chickens aged 15 days with a weight of $462.20 \pm 9$ grams of unsex Ross strain and nucleotides imported from China produced by CBH Co. Ltd., China. The study used a completely randomized design (CRD) with a $3 \times 3$ factorial pattern with 5 replications. The treatment was carried out at the age of 15-35 days. The treatment given was the first factor adding nucleotides $(\mathrm{T} 0=$ nucleotides $0 \mathrm{~g} / \mathrm{kg}$ feed, $\mathrm{T} 1=$ nucleotides $0.5 \mathrm{~g} / \mathrm{kg}$ feed, $\mathrm{T} 2=$ nucleotides $1 \mathrm{~g} / \mathrm{kg}$ feed) and the second factor was temperature $\left(\right.$ Heat $=\mathrm{S} 1=30-32^{\circ} \mathrm{C}$, Comfortable $=\mathrm{S} 2=20-23^{\circ} \mathrm{C}$, Natural $=\mathrm{S} 3=24$ $-34^{\circ} \mathrm{C}$ ). Parameters observed were protein content, calcium content, protein mass, and calcium mass of broiler chicken meat. The research data were analyzed using the $\mathrm{F}$ test of variance analysis, if there was a real treatment effect, then Duncan's test was continued. The results showed that there was no interaction between the addition of nucleotides with different maintenance temperatures on protein content, calcium content, protein mass, and calcium mass of meat. Nucleotide $0.05 \mathrm{~g}$ had a significant effect $(\mathrm{P}<0.05)$ on the protein content of the meat, the natural rearing temperature significantly affected the calcium content of the meat and the comfortable temperature had a significant effect on the protein mass of broiler meat. This study concludes that the addition of $0.05 \mathrm{~g}$ of nucleotides can meet the needs of nucleotide synthesis in the body of broiler chickens by increasing the protein content of the meat.
\end{abstract}

Key words: broiler chicken, nucleotides, rearing temperature, protein, and calcium.

\section{INTRODUCTION}

The increase in consumption of animal protein is increasing rapidly because it is accompanied by an increase in public awareness of the importance of animal protein for health. Broiler chicken is a poultry commodity that contributes significantly to the fulfillment of animal protein needs. Broiler chickens have several advantages, including fast growth because they can be harvested at the age of 5 weeks and can convert feed into meat very efficiently. Broiler chickens also have the disadvantage of being easily stressed and exposed to heat stress during maintenance in hot temperatures.

Indonesia is a tropical country that has 2 seasons, namely the dry season and the rainy season, resulting in unstable environmental temperatures. The instability of the environmental temperature causes heat stress so that the chicken is unable to synthesize nucleotides in its body and affects the performance of broiler chickens. Therefore, it is necessary to add nucleotides from the outside to suffice the synthesis of nucleotides.

Nucleotides are semi-essential nutrients consisting of bases, ribose sugars, and phosphate groups, which are needed in the growth and division process of broiler immune cells. Nucleotides from yeast extraction Saccharomyces cerevisiae are nucleotides rich in protein (Haldar et al., 2011). Broiler chickens fed yeast extract as a source of nucleotides in broiler diets numerically increased the yield of carcass, thighs, wings, and breasts compared to chickens that were not fed the yeast mixture. Nucleotides have a positive effect on broiler chickens exposed to heat stress. Nucleotides have an important role in the absorption of nutrients in the intestines to improve carcass quality in broiler chickens (Pelicia et al., 2010).

Nucleotides are non-nitrogen bioactive compounds that participate in the monomeric structure of DNA and RNA, function as coenzymes in various forms, and play an important role as biological regulators in metabolic reactions. The working system of nucleotides is in collaboration with nucleotidase enzymes which have a role in breaking down nucleotides and producing phosphate molecules to secrete purine and pyrimidine bases that play a role in the formation of DNA or the formation of new cells. The protein synthesis process involves DNA and calcium (Ca) activates DNA synthesis (Ralec et al., 2017). The high and low mass of 
meat protein is influenced by calcium levels in the form of ions (Winedar et al., 2006).

Factors that affect protein synthesis are hormones, enzymes, and vitamins. Process synthesis produces protein as a hormone producer so that hormones are one of the factors of protein synthesis, the enzymes needed are helicases to open DNA chains, polymerases to combine and make codon polymers, and then closed again by ligase enzymes and vitamins that have an effect including B2, B 6 and B 12 because many are in the meat.

The purpose of this study was to examine the effect of adding nucleotides in broiler rations to the protein mass and calcium mass of broiler chicken meat. The benefit of this study is that it can provide information about the addition of nucleotides in the ration of broiler chickens reared at high and unstable temperatures to overcome the production of nucleotide synthesis in the body of broiler chickens thereby increasing the protein mass and calcium mass of the meat.

\section{MATERIALS AND METHODS}

The materials used in this study were 135 broiler chickens aged 15 days with a weight of $462.20 \pm 9$ grams of Ross strain mixed male and female (unsex), starter feed produced by Charoen Pokphand with code B-11 MTK, nucleotide supplements imported from China produced by CBH Co. Ltd., China. The nucleotide content in the form of adenosine monophosphate (AMP), guanosine monophosphate (GMP), cytidine monophosphate (CMP), and uridine 5'monophosphate (UMP) with the same amount. The nucleotides used were extracted from yeast (Saccharomyces cerevisiae) by enzymatic hydrolysis. The feed ingredients used were corn, rice bran, MBM, soybean meal, limestone, DLMethionine, minerals, $\mathrm{NaCl}$, and coconut oil. The composition and nutritional content of the rations can be seen in Table 2. Lime, detergent, formalin, and KMNO4 were used for cage sanitation.

The tools used for the research are cages which are divided into 3 parts, namely hot, natural and comfortable where each section consists of 15 bulkheads equipped with feed and drink places. Analytical scales, knives, scissors, thermohygrometer for checking temperature and humidity, thermostat for checking the temperature in hot temperature enclosures, 1060 watt lamps for heat treatment, 1 AC for comfortable temperature treatment, ruler and tray used for data collection.
Table 1. Composition and nutrient content of ration

\begin{tabular}{lc}
\hline \multicolumn{1}{c}{ Feed Ingredients } & Composition \\
\hline & $-----(\%)-----$ \\
Corn & 62.00 \\
Soybean meal & 26.50 \\
bran & 4.00 \\
Meat bone meal (MBM) & 3.66 \\
Limestone & 0.25 \\
DL-Methionine & 0.09 \\
Mineral & 0.30 \\
NaCl & 0.20 \\
Coconut oil & 3.00 \\
\hline Total & 100.00 \\
\hline Nutrient content $(\%)^{*}$ & \\
\hline Crude protein & 18.90 \\
Metabolic energy $(\mathrm{kcal} / \mathrm{kg})$ & $3,145.50$ \\
Ca & 0.76 \\
P & 0.32 \\
Methionine & 0.38 \\
Lysine & 0.98 \\
\hline
\end{tabular}

*Nutrition and Feed Science Laboratory, Faculty of Animal Husbandry and Agriculture, Diponegoro University, Semarang.

\section{Experimental Design}

The experimental design used in this study was a completely randomized design (CRD) with a $3 \times 3$ factorial pattern consisting of 5 replications so that it consisted of 45 experimental units. Each unit is filled with 3 chickens for a total of 135 chickens. The first factor was the addition of nucleotides $(\mathrm{T} 0=$ nucleotides $0 \mathrm{~g} / \mathrm{kg}$ feed, $\mathrm{T} 1=$ nucleotides $0.5 \mathrm{~g} / \mathrm{kg}$ feed, $\mathrm{T} 2=$ nucleotides $1 \mathrm{~g} / \mathrm{kg}$ feed). The second factor is temperature (Heat $=\mathrm{S} 1$ $=30-32^{\circ} \mathrm{C}$, Comfortable $=\mathrm{S} 2=20-23^{\circ} \mathrm{C}$, Natural $=\mathrm{S} 3=24-34^{\circ} \mathrm{C}$ ). The parameters observed were protein mass and calcium mass of broiler chicken meat.

\section{Preparation phase}

The preparation stage begins with cage preparation and feeds preparation. Preparation of the cage was carried out using sanitizing the cage, liming, dividing the cage into 3 parts, installing lights for hot cages, and installing air conditioning for comfortable cages, as well as fumigating using formalin and KMNO4. Feed preparation is done by preparing the feed ingredients that will be used for the preparation of the ration.

\section{Implementation Stage}

Maintenance starts from the starter phase chickens until the age of 14 days. The treatment was carried out at the age of 15-35 days, namely adding nucleotide levels and maintenance at 
different temperatures, weighing body weight every week and recording feeding and temperature every day.

\section{Meat Sampling}

Sampling was carried out when the chickens were 35 days old at random, one tail per experimental unit. The chickens fasted for 12 hours, then weighed and cut and then weighed the carcass weight. Meat sampling for protein mass and calcium mass in the form of mixed meat samples from the breast and upper thigh. Each sample weighed $\pm 10 \mathrm{~g}$, mixed and homogenized and then put in a plastic flip for analysis of protein and calcium levels.

\section{Meat Protein Level}

Measurement of protein content using the Mikro Kjeldahl method (Bakhtra et al., 2017) by taking 1 gram of sample and then putting it into a tube with 1 gram of selen catalyst and $15 \mathrm{ml}$ of $\mathrm{H} 2 \mathrm{SO} 4$ added, then digested until the color is clear. After the destruction was completed, it was continued by distillation with $50 \mathrm{ml}$ of $0.1 \mathrm{~N} \mathrm{HCl}$ solution and added 2 drops of methyl orange in an Erlenmeyer and added 3 drops of $1 \%$ PP indicator. Furthermore, the sample is put into a distillation apparatus and given $\mathrm{NaOH}$ until the color becomes purplish. After the distillation is complete, then titrate with $0.0949 \mathrm{~N} \mathrm{NaOH}$ until it turns yellow to determine the protein content of broiler meat.

\section{Meat Calcium Level}

Measuring the calcium content of the meat is by homogenizing the samples of the chest and upper thighs as much as $10 \mathrm{~g}$. Samples of meat that have been homogenized, then weighed again as much as \pm 5 grams and put into a porcelain dish then baked for 1 hour then cooled and weighed again. The samples were then kilned at $600^{\circ} \mathrm{C}$ for 6 hours and then taken after \pm 12 hours. The meat sample after being roasted was then mixed with $30 \mathrm{ml}$ of aqua denim solution in a beaker and added $\mathrm{HCO} 3$ acid solution, then heated on a chemical heating stove and waited for it to boil. After boiling wait for 10 minutes then the stove is turned off and the solution is cooled. After cooling, the solution was added with $\pm 20 \mathrm{ml}$ of aquadenim and homogenized, and then filtered using filter paper and placed in a bottle.

\section{Meat Protein Mass and Calcium Mass}

Meat protein mass and meat calcium mass can be calculated using the formula Suthama (2003):

$$
\begin{array}{r}
\text { Meat Protein Mass = } \\
\begin{aligned}
\text { protein content }(\%) \text { X meat } & \text { weight }(\mathrm{g} / \mathrm{head}) \\
\text { Meat Calcium Mass }= & \text { meat calcium content }(\%) \\
& \text { X meat weight }(\mathrm{g} / \mathrm{e} \text { core })
\end{aligned}
\end{array}
$$

\section{RESULTS AND DISCUSSION}

\section{Meat Protein and Calcium Levels}

Based on Table 2. Statistical calculations showed that there was no interaction between the addition of nucleotides in broiler chicken rations at different rearing temperatures on protein content and calcium mass of broiler chicken meat. This shows that each factor affects without any interaction between the two factors.

Based on Table 2. Nucleotides have a significant effect $(\mathrm{P}<0.05)$ increasing the protein content of meat. The addition of 0.5 grams of nucleotides can increase the protein content of broiler meat by $22.15 \%$. This means that the addition of $0.5 \mathrm{~g}$ of nucleotides is sufficient to meet the shortage of nucleotide synthesis needs in broiler chickens compared to the addition of $1 \mathrm{~g}$ level of nucleotides. Jung (2011) stated that the addition of nucleotides in broiler rations of 0.25 $2 \mathrm{~g}$ was able to improve the performance of chickens compared to control feeds. The addition of nucleotides can increase the protein content of broiler meat because some feed ingredients contain nucleoproteins so that they can be used as a source of nucleotide synthesis as a protein synthesis material.

There was no significant effect $(\mathrm{p}>0.05)$ between the addition of different nucleotide levels to the calcium content of meat. This is because by absorption of calcium in a protein-bound form into meat is less than the absorption of calcium into other tissues. This is following the opinion of Nagara et al. (2019) which states that calcium transport is influenced by protein, where calcium enters the blood vessels and will be transported to other tissues that need it. The results showed that the calcium content was low while the protein content was high (Table 2.). This is not by the opinion of Lopez et al. (2000) which states that increased calcium levels are driven by high levels of meat protein because the process of absorption of a protein capable of binding calcium is called calcium-binding protein $(\mathrm{CaBP})$.

The treatment of different rearing temperatures showed that there was no significant effect between different temperatures on the protein content of the meat but it had a significant effect $(\mathrm{P}<0.05)$ on the calcium content of the meat (Table 2). 
Table 2. Meat protein and calcium levels

\begin{tabular}{cccc}
\hline Treatment & & Protein content $(\%)$ & Calcium level (\%) \\
\hline S1 & T0 & 21.89 & 0.000300 \\
& T1 & 22.46 & 0.000298 \\
& T2 & 20.79 & 0.000292 \\
\hline S2 & T0 & 22.06 & 0.000248 \\
& T1 & 22.26 & 0.000266 \\
& T2 & 19.35 & 0.000298 \\
\hline S3 & T0 & 20.74 & 0.000360 \\
& T1 & 21.72 & 0.000308 \\
& T2 & 20.17 & 0.000306 \\
\hline & T0 & $21.56 \mathrm{ab}$ & 0.000302 \\
& T1 & $22.15 \mathrm{a}$ & 0.000290 \\
& T2 & $20.10 \mathrm{~b}$ & 0.000298 \\
\hline & S1 & 21.71 & $0.000296 \mathrm{ab}$ \\
& $\mathrm{S} 2$ & 21.22 & $0.000270 \mathrm{~b}$ \\
& $\mathrm{~S} 3$ & 20.88 & $0.000324 \mathrm{a}$ \\
\hline P Value & T & 10.53 & 0.17 \\
& $\mathrm{~S}$ & 1.66 & 3.28 \\
& TxS & 1.03 & 1.11 \\
\hline
\end{tabular}

Information : Different superscripts in the same column showed significant differences $(\mathrm{P}<0.05)$.

The results of the highest protein content were at hot temperatures $(21.71 \%)$. The natural temperature of $24-34^{\circ} \mathrm{C}$ can increase the calcium content of the meat. Bikrisma et al. (2014) stated that broiler rearing temperatures ranging from 28 to $33^{\circ} \mathrm{C}$ were able to increase the value of calcium levels to increase the calcium mass of the meat as well. The high and low levels of calcium in meat are also influenced by protein levels because the absorption of protein along with calcium is called calcium-binding protein. The results showed that the highest calcium content at natural temperature, while the protein content at natural temperature is the lowest. This is not under the opinion of Nagara et al. (2019) which states that the higher the calcium content of the meat is because it is also influenced by the high protein content of the meat due to the process of absorption of protein along with calcium.

\section{Meat Protein and Calcium Mass}

Based on Table 3. Statistical calculations showed that there was no interaction between the addition of nucleotides in broiler rations at different rearing temperatures on protein mass and calcium mass of broiler chicken meat. This shows that each factor affects without any interaction between the two factors.

The addition of different nucleotide levels in the ration had no significant effect $(\mathrm{P}>0.05)$ on the protein mass of broiler meat. The mass of protein reared for 5 weeks obtained results ranging from $128,073 \mathrm{~g}-136,228 \mathrm{~g}$ where the results obtained exceeded the protein mass of broilers reared for 6 weeks Jamilah et al. (2013). Jamilah et al. (2013) stated that rearing broiler chickens for 6 weeks produced a protein mass of $79.18 \mathrm{~g}$ with consumption of $19.15 \%$ protein content. This is due to an increase in immunity so that protein is widely used for tissue repair and immunity, which ultimately reduces protein deposition into the meat. The higher the protein mass indicates that protein synthesis is going well as the high protein intake. This is by the opinion of Sari et al. (2014) state that protein deposition is supported by protein consumption and amino acid balance, if protein intake is a high protein synthesis substrate, then protein mass will also be high.

The addition of nucleotide levels had no significant effect ( $p>0.05)$ on the calcium mass of broiler chicken meat. This is influenced by the addition of nucleotides in the ration has not been able to increase the calcium content of broiler chicken meat (Table 3.). In addition, it is also influenced by the mass of meat protein which also has no significant effect, because of the absorption of protein along with calcium through the process of calcium-binding protein. Syafitri et al. (2015) stated that the increase in the calcium mass of meat can be influenced by $\mathrm{CaBP}$ which plays a role in carrying calcium to intestinal mucosal cells and entering blood vessels and then to tissues that need it. 
Table 3. Meat protein and calcium mass

\begin{tabular}{lccc}
\hline Treatment & & Protein Mass $(\mathrm{g})$ & Calcium Mass $(\mathrm{mg})$ \\
\hline S1 & T0 & 123.967 & 1.697 \\
& T1 & 134.674 & 1.789 \\
& T2 & 128.679 & 1.816 \\
\hline S2 & T0 & 139.390 & 1.568 \\
& T1 & 143.571 & 1.731 \\
& T2 & 130.827 & 2.011 \\
\hline S3 & T0 & 120.862 & 2.116 \\
& T1 & 130.440 & 1.854 \\
& T2 & 125.321 & 1.933 \\
\hline & T0 & 128.073 & 1.794 \\
& T1 & 136.228 & 1.792 \\
& T2 & 128.276 & 1.902 \\
\hline & S1 & $129.107 \mathrm{ab}$ & 1.767 \\
& S2 & $137.930 \mathrm{a}$ & 1.770 \\
& S3 & $125.541 \mathrm{~b}$ & 1.968 \\
\hline P Value & T & 0.169 & 0.661 \\
& S & 0.040 & 0.368 \\
& TxS & 0.795 & 0.583 \\
\hline
\end{tabular}

Information : Different superscripts in the same column showed significant differences $(\mathrm{P}<0.05)$.

This is also supported by the opinion of Ralec et al. (2017) which states that protein and calcium are interconnected because protein synthesis involves DNA and calcium plays a role in activating DNA synthesis.

A comfortable ambient temperature had a significant effect $(p<0.05)$ on the mass of meat protein because a comfortable cage environment temperature would also support the formation of meat protein mass. This is in accordance with the opinion of Wijayanto et al. (2018), the environmental temperature conditions of the cage between $19-280 \mathrm{C}$ support the process of forming meat protein mass, while temperatures above $28 \mathrm{oC}$ support the breakdown of protein in tissues. Broilers reared for 5 weeks showed that the highest protein mass was $137.93 \mathrm{~g}$. This shows that the results obtained are greater than previous studies. Mirnawati et al., (2013) stated that the protein mass of broiler meat with the provision of $22.01 \%$ protein rations reared for 5 weeks obtained results of $109.99 \mathrm{~g}$.

Different rearing temperatures had no significant effect $(\mathrm{P}>0.05)$ on the calcium mass of broiler chicken meat. The results show that the mass of calcium is low. These results are also influenced by protein mass, which if high protein mass will result in low calcium mass. This is following the opinion of Wijayanto et al. (2018) which states that the high and low calcium mass of meat is also influenced by the mass of meat protein, if the calcium mass is low then the protein mass is high or vice versa.

\section{CONCLUSION}

Based on the results of the study, it can be concluded that there is no interaction between maintenance temperature and the addition of nucleotide levels to the mass of calcium and protein mass of broiler meat. The addition of nucleotides significantly affected the protein content of the meat, while different temperatures had an effect on the calcium content and protein mass of broiler meat but had no significant effect on the calcium mass. Nucleotide $0.5 \mathrm{~g} / \mathrm{kg}$ feed is sufficient for nucleotide synthesis in broiler chickens.

\section{REFERENCES}

Bakhtra, D. D. A, R. Rusdi, dan A. Mardiyah. 2017. Penetapan kadar protein dalam telur unggas melalui analisis nitrogen menggunakan metode kjeldahl. J. Farmasi Higea 8 (2) : $143-150$.

Bikrisma, S. H. L., L. D. Mahfudz, dan N. Suthama. 2014. Kemampuan produksi ayam broiler yang diberi tepung jambu biji merah sebagai sumber antioksidan alami. J. Ilmu dan Teknologi Peternakan 3 (2) : 69 75 . 
Haldar, S., T. K. Gosh dan M. R. Bedford. 2011. Effect of yeast (Saccharomyces cerevisiae) and yeast protein concentrate on production performance of broiler chickens exposed to heat stress and challenged with salmonella enteritidis. Animal Feed Science and Technology 162 (2): $61-71$.

Hanifa, R. 2014. Kadar protein, kadar kalsium dan kesukaan terhadap cita rasa chicken nugget hasil substitusi terigu dengan mocaf dan penambahan tepung tulang rawan. J. Pangan dan Gizi 4 (2) : 53 - 60.

Jamilah, N. Suthama dan L. D. Mahfudz. 2013. Performa produksi dan ketahanan tubuh broiler yang diberi pakan step down dengan penambahan asam sitrat sebagai acidifier. JITV. 18 (4) : 251 - 257.

Jung, B. 2011. Evaluation of dietary nucleotides for broilers. University of Georgia. (Doctoral dissertation)

Lopez, H., C. Coundray, M. Levrat-Verny, C. Feillet-Coudray, C. Demigne and C. Remesy. 2000. Fructooligosaccharides enhance mineral apparent absorption and counteract the deleterious effects of phytic acid on mineral homeostasis in rats. J. Nutr. Biochem. 11: 500 - 508.

Mateo, C. D. and Stein, H. H. 2004. Nucleotides and young animal health: can we enhance intestinal tract development and immune function? In nutritional biotechnology in the feed and food industries. Proceedings of Alltech's 20th Annual Symposium: reimagining the feed industry, Lexington, Kentucky, USA, 23 - 26 May 2004. 1: 1 28.

Mirnawati., B. Sukamto dan V. D. Yunianto. 2013. Kecernaan protein, retensi nitrogen dan massa protein daging ayam broiler yang diberi ransum daun murbei (Morus alba $L$.) yang difermentasi dengan cairan rumen. JITV. 3 (1) : $25-32$.

Nagara, R. L. K., S. Kismiati, S. Setyaningrum dan L. D. Mahfudz. 2019. Massa protein dan kalsium daging ayam broiler akibat penambahan sinbiotik dalam ransum. J. Peternakan Indonesia 21 (3) : 198 - 204.

Pelicia, V. C, J. R. Sartori, K. C. Zavarize, A. C. Pezzato, A.C. Stradiotti, P. C. Araujo, M. A. O. Mituo dan L. A. Madeira. 2010. Effect of nucleotides on broiler performance and carcass yield. Brazilian Journal of Poultry Science 12 (1): 31 - 34 .

Ralec, C., E. Henry, M. Lemor, T. Killelea dan G. Henneke. 2017. Calcium-driven DNA synthesis by a high-fidelity DNA polymerase. Nucleic Acid Research 45 (21) : 12425 - 12440 .

Sari, K. A., B. Sukamto dan B. Dwiloka. 2014. Efisiensi penggunaan protein pada ayam broiler dengan pemberian pakan mengandung tepung daun kayambang (salvinia molesta). J. Agripet 14 (2) : $76-$ 83.

Suthama, N. 2003. Metabolisme protein pada ayam kampung periode pertumbuhan yang diberi ransum memakai dedak padi fermentasi. J. Pengemb. Pet. Tropical. Edisi Spesial, Hal. $44-48$.

Syafitri, Y. E., V. D. Yunianto dan N. Suthama. 2015. Pemberian Ekstrak Daun Belumtas (Pluchea Indica Less) dan Klorin terhadap Massa Kalsium dan Massa Protein Daging pada Ayam Broiler. J. Animal agriculture 4 (1) : $155-164$.

Wijayanto, B., U. Atmomarsono dan W. Sarengat. 2018. Pengaruh frekuensi penyajian ransum yang berbeda terhadap rasio efisiensi protein, massa protein daging dan massa kalsium daging ayam kampung super. J. Pengembangan Penyuluhan Pertanian. $15(28): 15-23$.

Winedar, H., S. Listyawati, dan Sutarno. 2006. Daya cerna protein pakan, kandungan protein daging dan pertambahan berat badab ayam broiler setelah pemberian pakan yang difermentasi dengan effective microorganisms-4 (EM-4). J. Bioteknologi $3(1): 14-19$. 